\title{
Research on the Application of Internet + in Electric Power Marketing
}

\author{
Songxue Hou ${ }^{1, a, *}$, Ying Wang ${ }^{1, b}$, Dan $\mathrm{Xu}^{1, \mathrm{c}}$, Yan Liu ${ }^{1, \mathrm{~d}}$, Qibing Yang ${ }^{1, \mathrm{e}}$ \\ Technical training center of Hubei electric power company, China

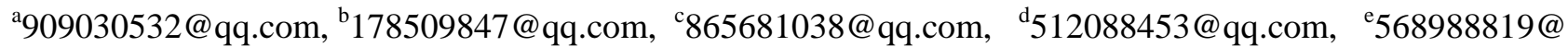 \\ qq.com \\ *Corresponding author
}

Keywords: Internet +; electric marketing system; marketing management; knight service; technical support platform.

\begin{abstract}
In the wake of the modern enterprises institution and the market reform of power industry improvement thoroughly, the disparity between traditional marketing model and the new historical background is becoming increasingly acute. Fortunately, Internet + could solve practical problems in Electric Power Marketing. This paper analyses the newest application of Internet + in Electric Power Marketing, and at the same time proposes several strategies from the aspects of marketing management, knight service and technical support to settle the inadequacies during application. At last, this paper explores the future possibilities and research area of the Internet + application in Electric Power Marketing (IPEPM).
\end{abstract}

\section{Introduction}

"Internet +" means the spread and application of a whole set of information technologies (including mobile Internet, cloud computing, big data technology, etc.) in the economy and social life, and it is the combination and promotion of the new generation of Internet technology and traditional industries. As a product of a new generation internet technology revolution, cloud computing, Internet of things and the big data technology constantly tend to mature and come into the application stage. They have merged with traditional industries, such as retail, manufacturing and finance, to form a new model. As the terminal link of electric power value chain, power marketing has the characteristics of multiple points, broad sides and long lines. It needs to complete the sales of electric products and assume the customer service work in the marketing scope. Therefore, the electricity marketing is not only regarding the final reflection of the power grid enterprises economic benefit, but also the external image and brand of the power grid enterprises. Electric power marketing business has taken place great changes along with the development of computer and communication technology, and the traditional working has largely replaced by the computer and other new technology. The high degree of automation and intelligent management, reasonable management system and business process, which broke the regional segmentation, shortened the working time, make electric power production and customer consumption more close, service more convenient and efficient. Therefore, the introduction of Internet technology in power marketing is the inevitable development of the times.

Represented by Europe, the United States and Japan build a smart grid system based on Internet technology, and emphasis on the demand side management. The main goal of marketing work is provide quality marketing services, the main principles is customer first, and the important indicator of marketing work is customer satisfaction. Depends on the application of Internet technology, Britain's electricity customers can choose by week, month, season and other different cycles and use a variety of ways such as cash, check clearing electricity, which formed a relatively complete system of price. The United States Southern California Edison company has invested heavily in the introduction of Internet technology. Their distribution network have made automatic transformation 
and a third of its 1300 lines can achieve automatic fault isolation. Japan applies Internet + technology, sets the time difference, season and other kinds of difference in the electricity price list. It is a good way to solve the problem of the gap between electricity load peak and valley in Japan a few years ago.

Domestic power grid enterprise applying "Internet +" makes Electricity marketing meter reading, accounting, charges as a priority. Namely automatic remote meter reading, electricity and electricity charge intelligence calculation, electricity bill socialization or electronic payment, etc. At the same time, the domestic power grid companies are actively promoting "the repair order electronic", trying to realize electronic work order application on industry expansion reporting, business change, pay fee, etc. The business outlet accepts the electronic work order, and then the customer carries on the offline consumption and the experience. In addition, the application of "Internet + " is also expected to realize intelligent "check", when the electric power enterprises realizing the whole electric power marketing business, the whole process, all jobs of on-line monitoring, multidimensional analysis, problem diagnosis. Finally, the marketing audit is transformed from "problem management" to "intelligent control mode". With Internet products and thinking permeating all aspects of people's lives and jobs, grid enterprises should adapt to the development of The Times, and launch a series of interactive "customer service Windows" through the application of "Internet +". For example, customers can operate autonomously through alipay, WeChat service number, etc., and pay attention to online payment and electricity information. Client can realize online customer service, business handling inquiries and more intelligent services through the palm power APP, 95598 service interactive website, electric e bao, etc.

\section{Current problems of power marketing}

Under the background of "Internet +" and the deep integration of electric power marketing, the power grid enterprises have developed rapidly and achieved great results, but there are still many problems. Since the reform of power system, electricity customers can deal with power generation enterprises and electric companies directly, and the power enterprises are facing increasing competition. However, China's power enterprises have long been in a monopoly position, and power marketing lacks competitive consciousness, resulting in insufficient competitiveness. Power enterprises should realize the problems of management, service, technology and other aspects of electric power marketing in order to survive and develop.

First of all, the marketing management level is low, which is reflecting in the backward management concept of electric marketing management, imperfect power marketing management mechanism, and low comprehensive quality of power marketing management personnel. For example, most of the electric power enterprise production concepts are still relatively backward. Corporate leaders and employees lack knowledge of Internet marketing and marketing informatization in electric power marketing. They still carry out production activities with marketing as the center, which affecting the development of power enterprises. Traditional processes, systems, standards, forms and other elements are scattered in the form of documents. It is difficult for employees to fully understand the system management requirements. The staff's manual is prepared by hand, which is easily causing the separation phenomenon of the system and implementation. And it is difficult to adapt the rapid change of organizational structure and management requirements. Lack of attention of the management, the training of staff is not enough and the assessment system is not scientific. Which leading to the professional skills and comprehensive quality of the power marketing management personnel are not high.

Secondly, in the process of power marketing services, there are problems such as poor service quality and low efficiency, resulting in low satisfaction of customers' service. For example, there are some problems such as newspaper loading, low voltage, power failure and slow recovery in individual areas, and the solving cycle of the problem is long. There are more information, more links, more examination and approval, longer time limit in business expansion report. The application coverage of 95598 interactive service website and service hotline, mobile phone 
client and WeChat public number is not very large. There are significant differences in standards, functions, friendliness, convenience and mutual substitution between different types of power supply service channels, which can not realize the service channel business for seamless docking. For the services demand of business change, distributed power supply access services and so on. Customers need to go back and forth between the power supply business hall and the scene many times. The service methods are mainly face to face, telephone, SMS, fax, E-mail and other service methods are less applied. Customer self-service only focuses on simple services such as electricity payment and electricity consumption, which cannot meet the customer's online interactive service experience needs.

In addition, lack of technical support system. It is embodied in the lower system practical application level, customer data collection and analysis ability insufficiency, the enterprise internal department's data interaction difficulties, information value-added service for the customer support insufficiently. For example, the on-line rate of the measurement automation system and the automatic meter copy rate are not high. The mode of centralized control of information system needs further optimization. Production management system, dispatching automation control system and marketing information system have not achieved the real-time connectivity. Associated data updating and supplementary work cannot be synchronized, which affect ting marketing service work efficiency. The application of marketing operation data is limited to the management analysis of professional statistical analysis and the statistical work of business indicators. Lacking of standardized management of unified information cannot be realized and Shared by the outside world.

\section{Research on power marketing application strategy}

Grid enterprises use "Internet +" in power marketing to improve the degree of management, service and technology. As a whole, the application of "Internet +" is still weak and scattered. It is necessary to further integrate to give full play to the role of power marketing. From the strategy, it should be based on improving marketing management. Its aim is providing quality service and its means is building the technical support platform.

\subsection{Optimize the marketing management mechanism}

Under the "Internet + " background, the marketing management mechanism of the power enterprise should tend to become scientific, standardized and unified, to be able to achieve efficient and convenient service. But at present, there are many problems in power marketing management, such as complicated operation, chaotic process, more links, time is too long, etc, causing that the data cannot be comprehensive and systematic management cannot communicate effectively with customers and meeting the actual needs of customers. Should be based on the concept of the mechanism as a means of personnel training as the core to enhance marketing management.

Firstly, the new concept of "Internet +" should be established in the management of electric power marketing. "Internet + " electric power marketing is not a simple power supply services on the Internet, but the goal of the new marketing management philosophy is with blending the Internet thought, method, technology, taking the customer as the centre, taking the market as the guide, as well as using to drive with big data, and with aim of customer satisfaction.

Secondly, we should improve the marketing management mechanism under the background of "Internet +". Through optimization of business process system, dynamic improvement of position responsibilities, strict performance appraisal system and so on, it is finished. In the process of optimization of business process system, we should get through the channel of the administrative interface, form the employee task switching automatic docking, and realize and transmit efficiently between all the professional marketing, and other management tasks. In dynamic improvement job responsibilities, we should match the elements associated with the process of management to the process after the smallest unit - process link, when we change in organizational structure and job. In the business process management requirements can be timely and accurately to implement new 
organizations and jobs; In strict performance appraisal system, we should set science appraisal system, strict management, strengthen the assessment results evaluation procedures link, and improve the inspection efficiency, as well as be people-oriented, have evidence and achieve results by cash to self-control.

Finally, strengthen the construction of the power marketing talent team under the "Internet +". Combined with the company human resources present situation, the current marketing is based on division of responsibility, by focusing on training, remote self-study, certification assessment, tournament competition, exchanges and cooperation to enhance the level of electric power marketing personnel management, information and to accumulate strength for enterprise development. As for curriculum system we must focus on take-off hillock training courses, solicit opinions from the course on a regular basis, custom combination course, and have all kinds of shortterm set culture class, on-demand application for employees, to participate in the training of qualified, after accumulating credits in personnel files. We should arrange various kinds of talents and reserve teams at various levels to train in various positions to improve the comprehensive quality; we should strengthen the cooperation of school enterprises and broaden the professional vision of the whole staff.

\subsection{Improve 020 platform service level and quality}

As an innovative product of marketing service under Internet + , electric power marketing $\mathrm{O} 2 \mathrm{O}$ is a means of improving knight service. Shorted for Online To Offline,O2O means to buy products and service online, but get service offline, shown as Figure 1. Electric power marketing O2O service should reach the following three goals, first, get the offline traditional service integrated and bring them online to reach smart application, secondly, make the online service and channels integrated by the construction of online operation channels, thirdly, the online service drive the offline service to drive online customers, guide the online customers to experience the service offline in order to get knight service. Through O2O service business integration, online service integration and $\mathrm{O} 2 \mathrm{O}$ service experience, electric power marketing $\mathrm{O} 2 \mathrm{O}$ service is developed with the idea of Internet +. By perfecting online channels and integrating online and offline resources, traditional marketing service front end and background is separated, the whole business management procedure is controlled, and cross-sector cohesion is reached which make the business run in high efficient and provide the customers experiential service based on Internet.

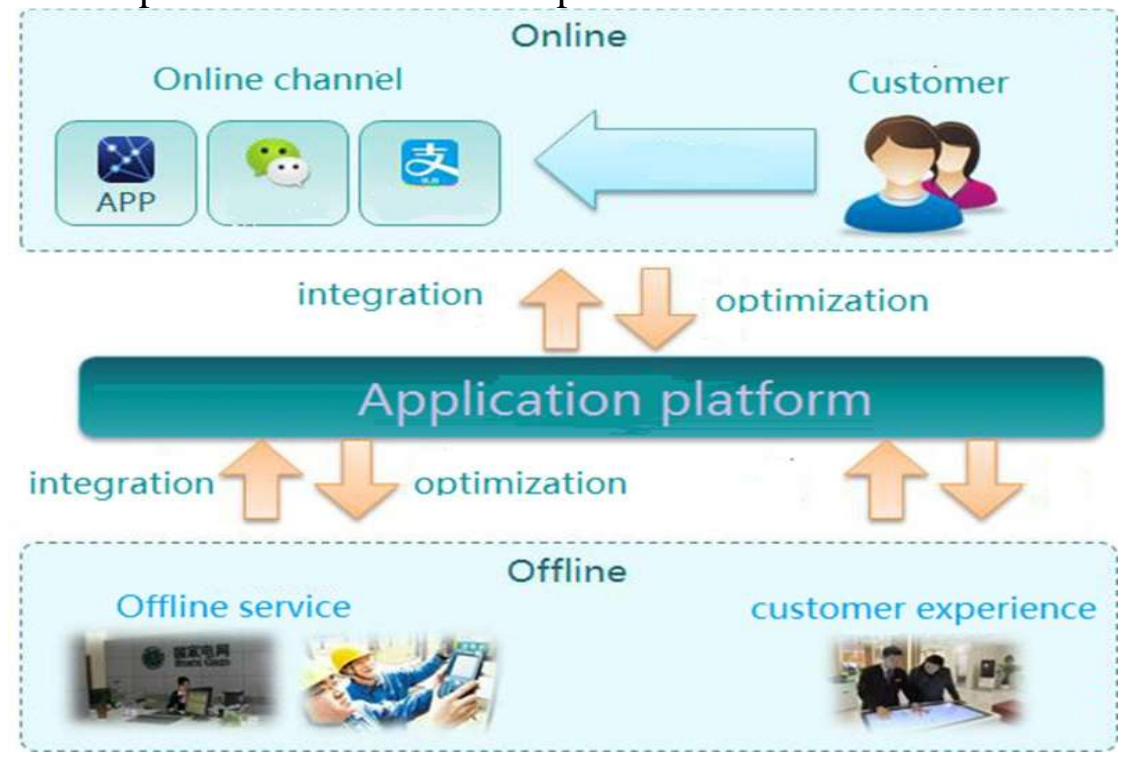

Figure 1 Electric power marketing $\mathrm{O} 2 \mathrm{O}$ service

With help of building smart electric power marketing integration platform, electric power marketing $\mathrm{O} 2 \mathrm{O}$ service integration get all the data in the inner system such as electric grid company marketing business system, 95598 system, electricity information acquisition system, integrated payment platform and so on integrated to drive the offline business integrated online in order to 
form a complete and overall business data pool. In the meantime, the platform is docked with electronic channels like pocket electric power APP, 95598 online business hall, Alipay, WeChat, SMS,E-mail and so on, in order to get the data of platform integrated online. By the construction of business handling mechanism such as business supervision, channel coordination, customer management and so on, the inner business handling and online service is joint seamlessly in the real business.

Based on the widely used of internet + , electric power marketing $\mathrm{O} 2 \mathrm{O}$ service online integration is access to smart electric power marketing integration plat-form uniformly by building electronic channels, and take the off-line business to online for customers to manage, which can provide the customers 24hour, no-geographical limitation service. All channels support online service integration shown as Table 1.

Table 1 Online service integration.

\begin{tabular}{|c|c|c|c|c|c|c|c|}
\hline $\begin{array}{l}\text { Online } \\
\text { Service }\end{array}$ & $\begin{array}{l}\text { One- } \\
\text { line } \\
\text { payment }\end{array}$ & $\begin{array}{l}\text { businssexpansion } \\
\text { report }\end{array}$ & $\begin{array}{l}95598 \\
\text { Business(consult, } \\
\text { advise, } \\
\text { complaints, } \\
\text { report) }\end{array}$ & $\begin{array}{l}\text { Malfunction } \\
\text { Service) }\end{array}$ & $\begin{array}{l}\text { Online } \\
\text { booking }\end{array}$ & $\begin{array}{l}\text { Subscription } \\
\text { information }\end{array}$ & $\begin{array}{l}\text { Information } \\
\text { disclosure }\end{array}$ \\
\hline $\begin{array}{l}\quad \text { Pocket } \\
\text { Electric } \\
\text { Power }\end{array}$ & $\sqrt{ }$ & $\sqrt{ }$ & $\sqrt{ }$ & $\sqrt{ }$ & $\sqrt{ }$ & $\sqrt{ }$ & $\sqrt{ }$ \\
\hline $\begin{array}{l}\text { We-chat } \\
\text { Official } \\
\text { Account }\end{array}$ & $\sqrt{ }$ & $\sqrt{ }$ & $\sqrt{ }$ & $\sqrt{ }$ & $\sqrt{ }$ & $\sqrt{ }$ & $\sqrt{ }$ \\
\hline $\begin{array}{l}\text { Ali-pay } \\
\text { Service } \\
\text { Window }\end{array}$ & $\sqrt{ }$ & & $\sqrt{ }$ & & $\sqrt{ }$ & $\sqrt{ }$ & $\sqrt{ }$ \\
\hline $\begin{array}{c}\text { Online } \\
\text { Business Hall }\end{array}$ & $\sqrt{ }$ & $\sqrt{ }$ & $\sqrt{ }$ & & & $\sqrt{ }$ & $\sqrt{ }$ \\
\hline $\begin{array}{c}\text { SMS } \\
\text { Platform }\end{array}$ & & & & & & $\sqrt{ }$ & \\
\hline $\begin{array}{c}\text { Mail } \\
\text { Platform }\end{array}$ & & & & & & $\sqrt{ }$ & \\
\hline
\end{tabular}

Smart electric power marketing O2O service mode experience can help to meet customer's multiple experience demand by the construction of customer experience zone, through which, customers can get interactive experience, electric vehicle supporting service experience, customer's tag service experience, customer integral experience, credit integral compensation service, demand side active respond service, personalized Value-added service and so on. We should aim to improve customers experience, meet customers demand and adapt to the development trend of social environment. Electric power marketing $\mathrm{O} 2 \mathrm{O}$ service experience will develop a totally new experience mode, as shown in Figure 2: 


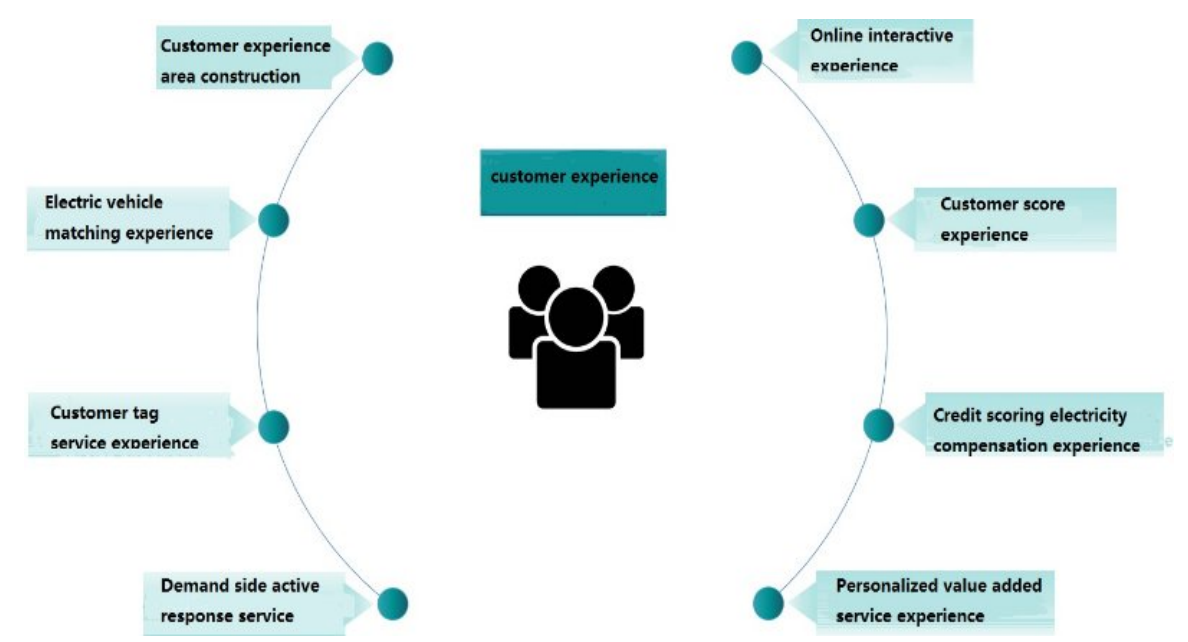

Figure $2 \mathrm{O} 2 \mathrm{O}$ service mode based on Internet + electric power marketing

\subsection{Perfect technology and assorted supporting system}

On the background of Internet + , in order to build electric power marketing technology support plate-form, we need to ensure the uniform standard and criterion, high efficient analysis and decision making in data, high cohesion and low coupling among all modules to reach quick respond of operation and maintenance and settlement, reaching safe operation of data flow, information flow and job flow to keep long time of stable operation with safe and reliable environment in security defence.

Firstly keep data in a standard way. We should form company data standard system by developing data technology standard, application standard, security standard, management and service standard open standard to form according the general requirements of State Grid Corporation information standard. We also need to focus on the development of data collection, exchange, open and application standard, clear the data management right, open strategy, application scope and visit way, and guide and standard the construction and operation and maintenance of company electric power marketing. For example, during the construction of camp fiscal integration subsystem, after the data between marketing and finance is uniform, the counterparts of the camp fiscal integration subsystem, marketing business application subsystem and financial management and control system can be integrated, the relative business effectively fused and horizontal synergy obstacles broken. Secondly, high efficient analysis and decision making should be ensured. Electric power marketing technology plat-for supports the information interaction among energy suppliers, energy service suppliers and energy consumers, to realize accurate electric quantity and fee calculation, exact statistics analysis and automatic decision making. For example, analysis potential demand and position consumer groups to support data for launch personalized marketing, and expand marketing market and develop new product strategy according to analysis result.

In terms of function flow-sheet, operation and maintenance integration should be reached. According to the principle of high cohesion and low coupling, the coupling degree between very subsystem and balanced system should be reduced and the integration and interaction between subsystem interface and outer system should be optimized. Integrate the upstream and downstream business, the relative specialty, to improve demand and service speed.. For example, when build the Remote real-time fee control sub system, reduce the coupling degree between Remote real-time fee control application and marketing system, make the application function modes which have high cohesion degree with the main part of fee control business flow-sheet such as fee control strategy management, data preparation, electric bill measurement, electric bill audit, baseline comparison and fee control strategy analysis and execution those that scattered in marketing business application system as the boundary of marketing real-time fee control plat-form, in order to reduce frequent interaction. 
In respect of security defence, information safety should be insured. With the introduction of Internet + , the safety of information in electric power marketing is in even more urgent need. There is huge important information which affects the survival and development of the electric power enterprise in electric power marketing. However, in the mode of Internet, information is relatively concentrated, once there is hidden danger, the information is easy to be destroyed and illegally used. Therefore, through security management to ensure the information security to get reliable and accurate service in the innovation of electric power marketing. Such as, Firewall, Cryptography, Authentication and so on.

\section{Conclusion and Prospect}

Now, new technologies such as internet + , artificial intelligent develop in a strong trend, which make a big difference on and rebuild the management concept, service way and technology means. Accordingly there will be also a huge and deep change in the category, content and procedure of electric power marketing, all kinds of new fast, convenient and knight consumer experience are changing the consumption concept and electric power grid enterprise's service concept. In the meantime, the process of electric system innovation and energy revolution are accelerating. New founded electric selling companies come up constantly with strong will and being ready. New energy access, efficient service, electric vehicle, user storage, demand respond and energy internet are all coming in front of us, which also change the electric power marketing and service ecology all the time. Faced with whether the fast changing technology promotion, the competition in retail side, expansion in new domain, or providing base and data service after the open of power-sold side, electric power enterprises are all facing new challenges and opportunities. Shocked by the electric system innovation and energy revolution and effected by the more and more deepen integration of Internet + , new technology and marketing business, there will be a electric power marketing management with the means of scientific management mechanism, the core of building talent team, electric power marketing service with the purpose of providing knight service, the centre of client, and a electric power marketing technical support plate-form with the base of big data, with the goal of efficient professional work.

\section{References}

[1]Hu Ruoyun, Xie Zhihan. Research and application of "Internet + " power marketing live audit mode[J]. eEnterprise management, 2016(S1):202-203.

[2]Gong Manqi, Tu Wenjia. The Strategy and Approach Electric Power Enterprise Marketing [J]. coal technology, 2012, 31(11):275-277.

[3] State Grid Communication[2015] No.251, the state company notice of printing <the Guiding Idea of State Grid Company Data Applications $>$ and < he Guiding Idea of State Grid Company Mobile Applications>.

[4]Zang Ningning. How the Electric Power Company Develop Market Marketing System under the Revolution of Electric Power System [J]. China Energy, 2016, 38(4):44-47.

[5]Jin Xuanjun, Zhang Danni, Cen Diqing. The Study of Main Problem and Countermeasure Electric Power Marketing Expansion in Electric Power Market[J]. East China Electric Power, 2014, 42(12):2662-2664.

[6]Li Dan, Shen Hao, Sun Wei the Explosion and Practice on the Base of 'Internet + Electric Power Marketing'[J]. Electric Power Demand Management, 2016, 18(z1):127-128.

[7]Wang Xun. The Explosion of the Innovative Method of Electric Power Marketing Organization Management[J]. Electric Power Demand Site Management, 2016, 18(5):38-40.

[8]Gong chengya, Chen ting, Wu xin ect. Internet + power marketing business operation mode exploration[J]. Electric Power Demand Site Management, 2016(A01):16-17. 
[9]Tu ying, Lin shiyong, Liu Lin, "Internet + marketing services" innovation model exploration and practice[J]. Electric Power Demand Site Management, 2016(A01):7-10.

[10]Hu Liwei, Wei yamin, Chen tongzhou. Research on the development trend of power grid enterprise customer service under the background of "Internet + " and power system reform[J]. Electric Power Demand Site Management, 2016(A01):71-73. 